\title{
Impact of Shading Net on Photovoltaic Cells Performance
}

\author{
Wahri Sunanda ${ }^{1}$, Rika Favoria Gusa ${ }^{2}$, Yuant Tiandho ${ }^{3}$, and Erick Aryana Pratama ${ }^{4}$ \\ ${ }^{1,2,4}$ Department of Electrical Engineering, Faculty of Engineering, Universitas Bangka Belitung \\ ${ }^{3}$ Department of Physics, Faculty of Engineering, Universitas Bangka Belitung
}

\author{
Kampus Terpadu Balunijuk, Merawang, Bangka, 33172, Indonesia \\ wahrisunanda@gmail.com ${ }^{1}$,rikafavoriagusa@gmail.com ${ }^{2}$,yuanttiandho@gmail.com ${ }^{3}$,erickaryanapratama@gmail.com ${ }^{4}$
}

\begin{abstract}
The output of the photovoltaic cells such as voltage and current is an essential parameter to assess the performance of photovoltaic cells. The performance of photovoltaic cells depends on the intensity of solar irradiation and the cleanliness conditions of cells. One of the factors that influence the performance of photovoltaic cells is shading. It can reduce the intensity of solar irradiation on the cells. In this study, the measurement system used two units of current and voltage sensors that simultane ously measu res the performance of photovoltaic cells. In photovoltaic cells covered by a shading net with nominal shading rates of $50 \%$ and $90 \%$, the average efficiency is $6 \%$ and $2 \%$ respectively. Meanwhile, for photovoltaic cells without covering by a shading net, the average efficiency is $11 \%$.
\end{abstract}

Keywords - photovoltaic, shading, current, voltage, efficiency

\section{INTRODUCTION}

The utilization of renewable energy in national energy policy in Indonesia is one of the priorities to meet national energy needs. Even in 2028, it can supply $23 \%$ of national energy needs [1]. One of the abundant renewable energy sources in Indonesia is solar energy. The government has a target to produce energy from this source up to $908 \mathrm{MWp}$ in 2028 [1]. The government has issued some regulations to encourage the utilization of photovoltaic cells. In addition, as a source of energy directly through the rooftop photovoltaic, the government proposes some supports such as creating a billing system to accommodate export-import offsets and providing credit deposits from photovoltaic consumers [2]. Some factor influences the efficiency of photovoltaic such as the type of PV material, solar radiation intensity received, cell temperature, parasitic resistances, cloud and other shading effects, inverter efficiency, dust, module orientation, weather conditions, geographical location and cable thickness [3]. In this paper, shading effect as one of factor that influences the efficiency of photovoltaic performance will be discussed.

Several studies related to the influence of the shading to the photovoltaic cells in both experimentally [4] - [17] and modelling have been conducted [18] - [20]. Besides, several studies related to photovoltaic cells monitoring [21] - [23] have also implemented to support the purpose of research, which is to observe the performance of photovoltaic under the influence of the shading nets. If a photovoltaic module is partially shaded, some of the cells will work in reverse bias. This causes the cell to act as loads and not as electrical generators. In addition, the presence of shade will reduce the intensity of the solar irradiation that illuminates the photovoltaic module. In one model, the intensity of irradiation is directly proportional to the current generated by photovoltaic cells [24]. Thus, the presence of shade will reduce the performance of photovoltaic modules.

The solar array simulator is commonly using to measure the characteristics of the dependence of the performance of the photovoltaic module on the intensity of the irradiation. However, the equipment has expensive costs. In this article, a measurement method is proposed to determine the dependence of the performance of the photovoltaic module on the irradiation intensity using shading nets. Shading nets is a tool that is generally used in plant cultivation and acts as a shade. The choice of using shading nets is because it has a specific shade rate. Thus, the uses of shading nets are expected to reduce measurement costs and can be an alternative in learning activities related to photovoltaic modules.

\section{METHOD}

This research uses a $50 \mathrm{Wp}$ photovoltaic panel with a size of $784 \times 506 \times 35 \mathrm{~mm}^{3}$ that is installed outdoors so that it can get direct sunlight. Then, the voltage sensor, current sensor, Arduino, solar charger controller and ESP8266 place in the room to protect from weather influences.

Shading nets were used to observe the effect of shade on the performance of photovoltaic. Two types of shading nets in this research were shading net-50 and shading net-90, which means the nominal shading rates are 50\% and $90 \%$, respectively. Figure 1 shows a comparison design between photovoltaic cells without shading net and photovoltaic covered by shading net. 


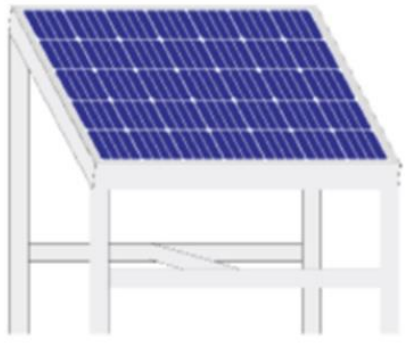

(a)

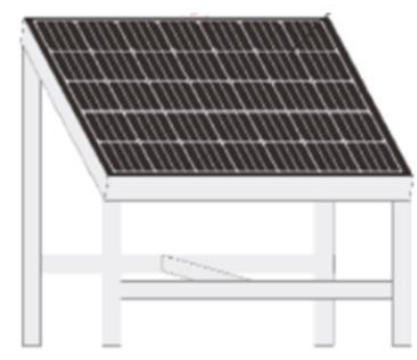

(b)
Figure 1. Photovoltaic panel design: (a) without shading net (b) covered by shading net

The wiring diagram of the monitoring system in this study is shown in Figure 2. Based on Figure 2, the device consists of two units of photovoltaic panels, two units of voltage sensors, two units of current sensors, Arduino, and ESP8266 module. The photovoltaic panel is connecting in parallel with the voltage sensor, i.e. the positive terminal of the photovoltaic panel is connecting to the VCC on the sensor, and the negative terminal of the panel is connecting to the GND on the sensor. Meanwhile, the solar panels are connected in series with the current sensor.

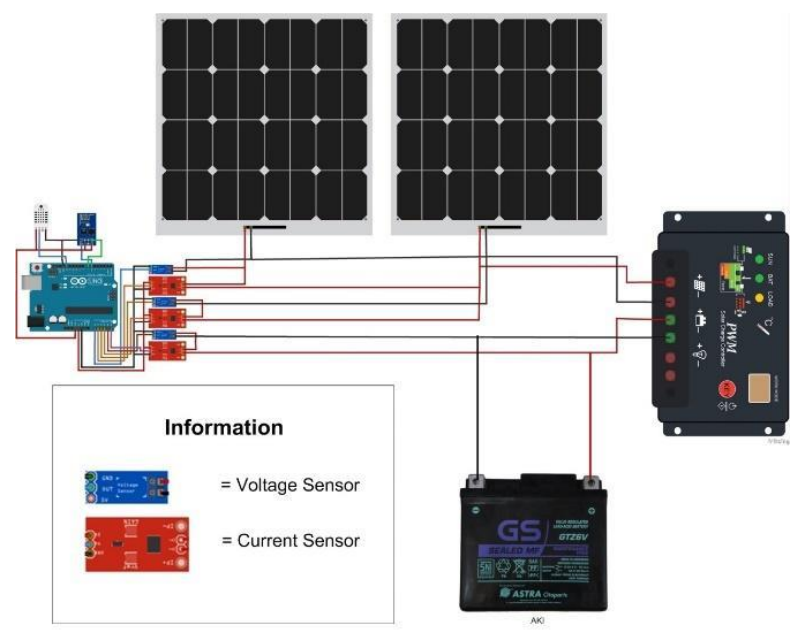

Figure 2. Wiring diagram

\section{RESULT AND DISCUSSION}

In Figure 3, the photographs of photovoltaic panels covered by shading net are presented. Based on these photos, it shows that the shading net-90 can obstruct solar irradiation intensity on photovoltaic panels more than the shading net-50. This is because the shading net-90 has a higher density than the shading net-50. Research several types of photovoltaic also show differences in current, voltage and power values when using shading net and with a 50\% shading net [7].

In Figure 4, photo-generated current data by photovoltaic panels that are illuminated by solar radiation at 8:00 - 12:00 $\mathrm{AM}$ are presented. The measured current in this data is obtained for current with lamp loads. Figure 4 shows the current measurements of photovoltaic without shading net and the range of current is $0.57-2.22 \mathrm{~A}$, with the average current of $1.31 \mathrm{~A}$. The measured current range for panel covered by shading net-50 is from $0.22-1.42 \mathrm{~A}$, with the average current of 0.69 A. Meanwhile, the measured current ranges for shading-90 is from $0-0.52 \mathrm{~A}$, with the average current of $0.19 \mathrm{~A}$. The temperature during the measurement is in the range of $31.4-38.8{ }^{\circ} \mathrm{C}$. Based on these results, the average current generated by photovoltaic panels covered by shading net-50 and shading net-90 decreased by $47 \%$ and $90 \%$ respectively.

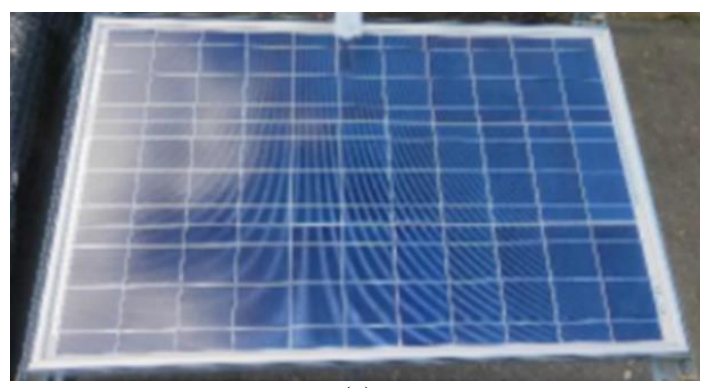

(a)

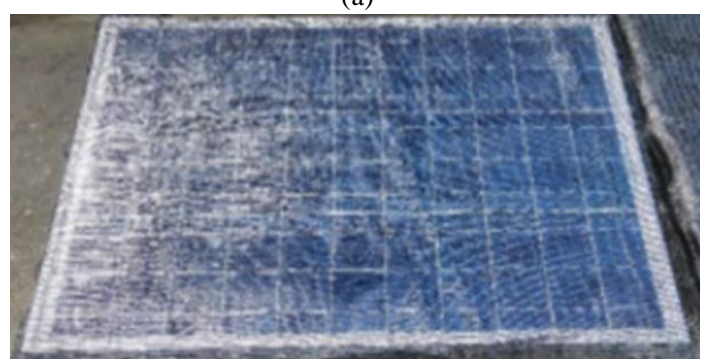

(b)

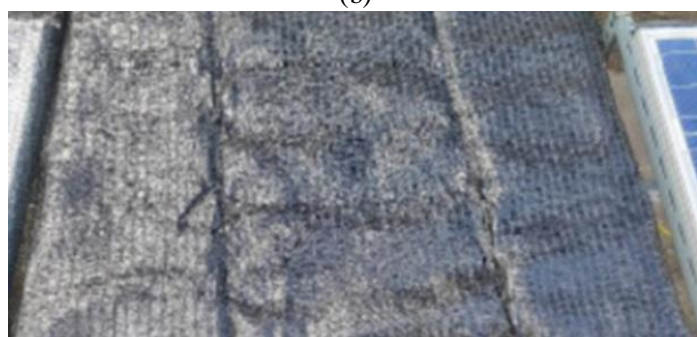

(c)

Figure 3. Photograph of photovoltaic panels: (a) without shading net, (b) covered by shading net -50 , and (c) covered by shading net -90 


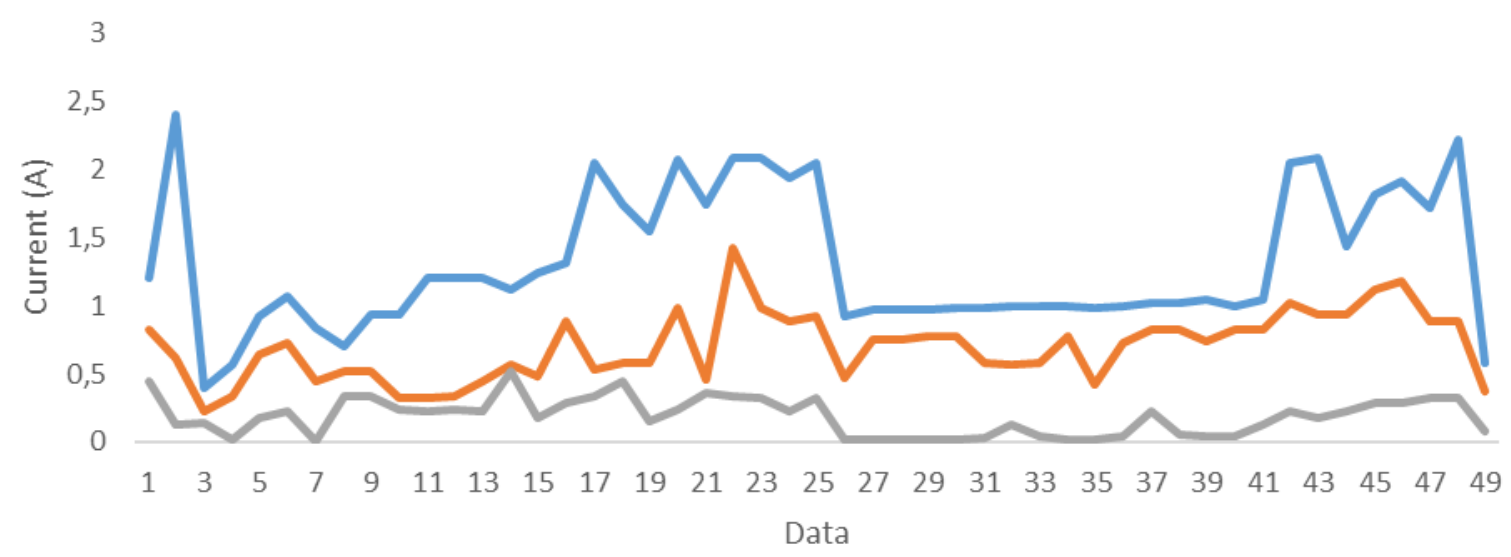

(a) Without Shading Net (b) Covered by Shading Net-50 (c) Covered by Shading Net-90

Figure 4. Photo-generated current by photovoltaic: (a) without shading net, (b) covered by shading net -50, and (c) covered by shading net-90

The decrement in the average photo-generated current in this study is proportional. This is in accordance with the model, which states that the relationship between current and solar irradiation that illuminated photovoltaic cells at the constant temperature satisfies the following equation [24]:

$$
I=I_{s t} \frac{G}{1000}(1+a)
$$

where $I_{s t}$ is photo-generated current at standard condition ( standard solar irradiance $=1000 \mathrm{~W} / \mathrm{m}^{2}$ and standard temperature $\left.=25^{\circ} \mathrm{C}\right), G$ is solar irradiance that illuminated photovoltaic cells, and $a$ is constant which related to temperature parameter. Solar irradiation received by photovoltaic cells without shading net, covered by shading net-50 and shading-90 are expressed in percentages, $100 \% \mathrm{G}_{0}$, $50 \% \mathrm{G}_{0}$, and $10 \% \mathrm{G}_{0}$, respectively, where $\mathrm{G}_{0}$ is solar irradiance without treatment. Through the substitution of these definitions in (1), the equation can be reduced to,

$$
I=\eta b+c
$$

where $\eta$ is the percentage of solar irradiation while $b$ and $c$ are empirical constants related to standard current and temperature. To validate the model, Figure 5 presents a comparison between the above model and the experimental results in this study. It appears that the experimental results are in accordance with the model in (2) with the value of $b=0.01244$ and $c=0.06639$. The accuracy of the model is expressed by $\mathrm{R}^{2}=0.999$.

Based on Figure 6, the measured voltage of the photovoltaic panel that is not covered by the shading net at 08.00 - 12.00 AM was between $13.04 \mathrm{~V}-18.94 \mathrm{~V}$ and the average measured voltage is $17.49 \mathrm{~V}$. As a comparison, the voltage generated by photovoltaic with shading net-50 ranges from $13.02 \mathrm{~V}-18.94 \mathrm{~V}$ with the average measured voltage is 17.49 V. Meanwhile, the maximum measured voltage for photovoltaic panel covered by shading net-90 is $18.9 \mathrm{~V}$ and the minimum voltage is $13 \mathrm{~V}$. The average voltage for this case is $17.52 \mathrm{~V}$.

The efficiency of the photovoltaic panel is calculated by some parameters such as peak voltage, peak current, solar intensity per square meter and surface area of the panel, and the results are shown in Figure 7. The range of efficiency of the photovoltaic panel covered by shading net-50 is $2.13 \%$ $15.30 \%$ with the average efficiency of $6 \%$, while the range efficiency of the photovoltaic panel covered by shading net-90 is $0 \%-7.49 \%$ with the average efficiency of $2 \%$. As a comparison, the range of efficiency of the photovoltaic panel without shading is $5.09 \%-22 \%$ and its average efficiency of $11 \%$.

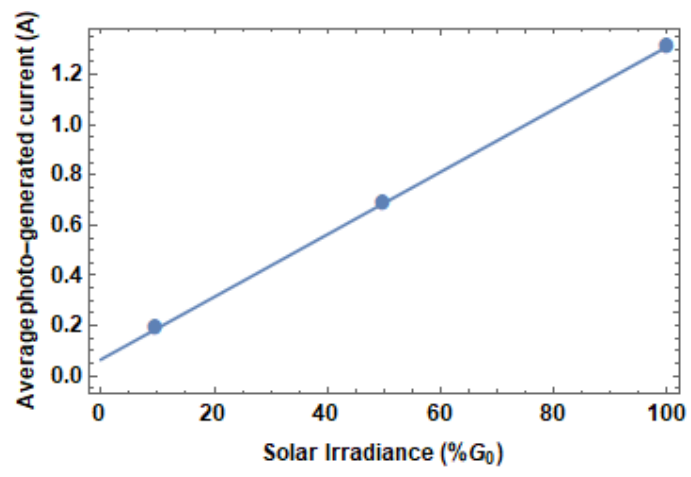

Figure 5. Comparison of measurement (dot) with the model (line) in (2) 


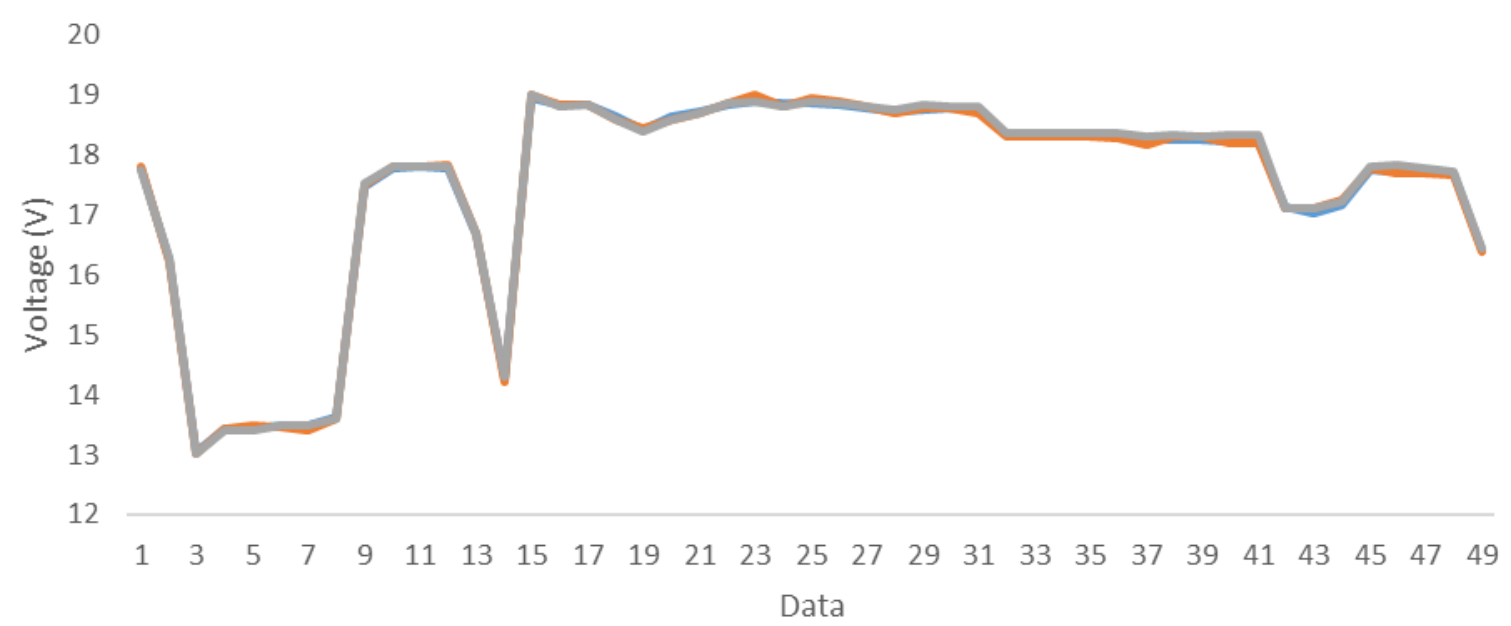

(a) without Shading Net (b) Covered by Shading Net-50 (c) Covered by Shading Net-90

Figure 6. Photo-generated voltage by photovoltaic: (a) without shading net, (b) covered by shading net-50, and (c) covered by shading net-90

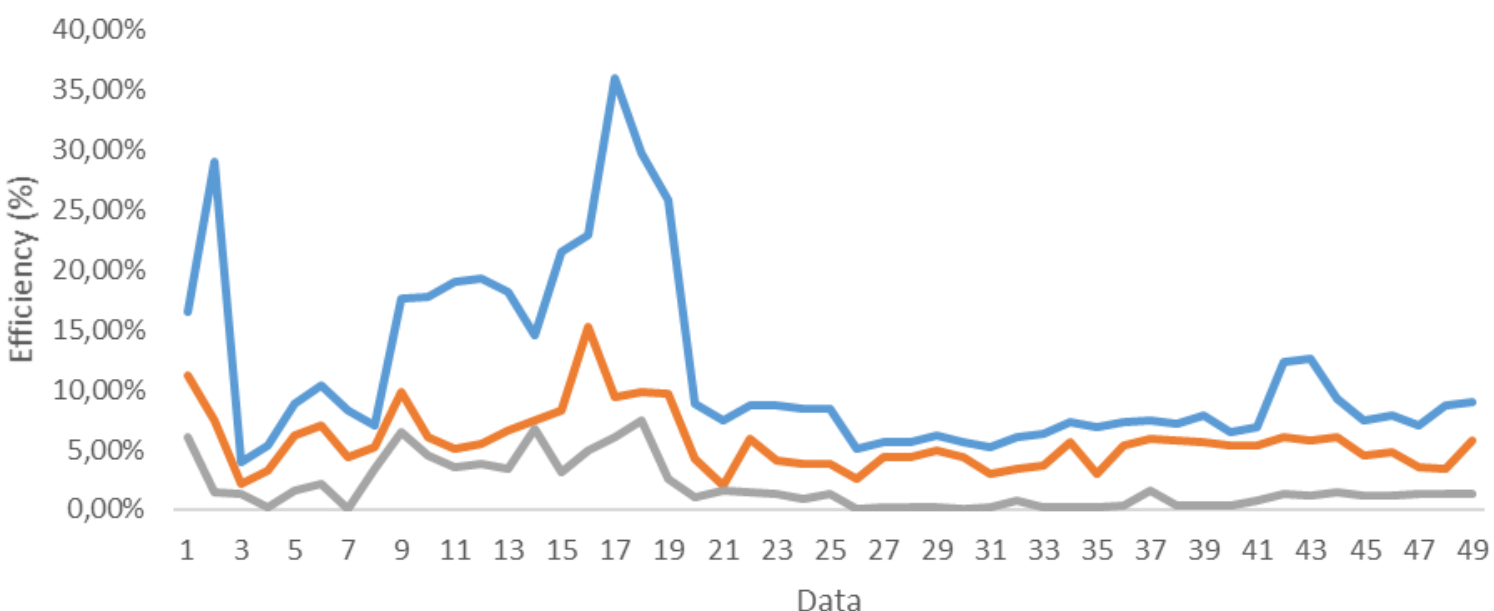

(a) without Shading Net (b) Covered by Shading Net-50 (c) Covered by Shading Net-90

Figure 7. The efficiency of photovoltaic: (a) without shading net, (b) covered by shading net -50 , and (c) covered by shading net -90

\section{CONCLUSION}

The shading net may decrease the performance of photovoltaic cells. Based on research, the average current of the photovoltaic panel without shading net is $1.31 \mathrm{~A}$. Meanwhile, the average current for photovoltaic panel covered by shading net-50 and shading net-90 are $0.69 \mathrm{~A}$ and 0.19 A, respectively. The average efficiency of the photovoltaic panel without shading net is $11 \%$, and the efficiencies of the photovoltaic panel covered by shading net 50 and shading net- 90 are $6 \%$ and $2 \%$ respectively. This certainly made the reason that the shading net hampered the solar radiation and consequently on photovoltaic performance.

\section{ACKNOWLEDGMENT}

We gratefully acknowledge the funding from USAID through the SHERA program - Centre for Development of Sustainable Region (CDSR). In year 2017-2021 CDSR is led by Centre for Energy Studies - UGM.

\section{REFERENCES}

[1] Rencana Umum Penyediaan Tenaga Listrik 2019-2028 (RUPTL), Kementerian ESDM, 2019.

[2] Diseminasi Rencana Umum Penyediaan Tenaga Listrik 2019-2028 (RUPTL), PT PLN(Persero), 2019.

[3] K. V. Vidyanandan, "An overview of factors affecting the performance of solar PV systems," Energy Scan, vol. 27, pp. 2-8,2017.

[4] I. H. Mahammed, A. H. Arab, Y. Bakelli, M. Khennene, S. H. Oudjana, A. Fezzani, and L. Zaghba, "Outdoor study of partial shading effects on different PV modules technologies," Energy Procedia, vol.141, pp. 81-85, 2017.

[5] P. Sathyanarayana, R. Ballal, P.L. Sagar, and G. Kumar, "Effect of shading on the performance of solar PV panel," Energy and Power, vol. 5, no. 1A, pp.1-4, 2015.

[6] M. Al-chaderchi, K. Sopain, M.A. Alghoul, and T. Salameh, "Experimental study of the effect of fully shading on the Solar PV module performance," in E3S Web of Conferences, vol. 23, p. 01001, 2017.

[7] S. Bimenyimana, G. N. O. Asemota, M. C. Kemunto, and L. Li, "Shading effects in photovoltaic modules: Simulation and experimental results," in 2017 2nd International Conference on Power and Renewable Energy(ICPRE), IEEE, pp.904-909, 2017. 
[8] L. Fialho, R. Melicio, V. Mendes, J. Figueiredo, and M. CollaresPereira, "Effect of shading on series solar modules: simulation and experimental results," in Conference on Electronics, Telecommunications and Computers - CETC 2013, Procedia Technology, vol. 17,pp.295-302,2014.

[9] R. Ramabadran and B. Mathur, "Effect of shading on series and parallel connected solar PV modules," Modem Applied Science, vol. 3, no. 10, pp. 32-41, 2009.

[10] Y. Sun, X. Li, R. Hong, and H. Shen, "Analysis on the effect of shading on the characteristics of large-scale on-grid PV system in China," Energy Power Eng, vol. 5 no. 4, pp. 215-218, 2013.

[11] F. Lu, S. Guo, T. M. Walsh, and A. G. Aberle, "Improved PV module performance under partial shading conditions," Energy Procedia, vol. 33, pp. 248-255, 2013.

[12] B. Aljafari, "Solar photovoltaic (PV) array under partial shading conditions," American Journal of Engineering Research, vol. 5 no. 6, pp. 123-126, 2016.

[13] S. Moballegh and J. Jiang, "Partial shading modeling of photovoltaic system with experimental validations," in 2011 IEEE Power and Energy Society General Meeting, IEEE, pp. 1-9, 2011.

[14] S. Lyden and M. E. Haque, "Modelling, parameter estimation and assessment of partial shading conditions of photovoltaic modules," Journal of Modern Power Systems and Clean Energy, vol. 7, no. 1, pp. 55-64, 2019.

[15] D. Sera and Y. Baghzouz, "On the impact of partial shading on PV output power," in WSEAS/IASME International Conference on Renewable Energy Sources, pp. 229-234, 2008.

[16] V. P. Deshpande and S. B. Bodkhe, "Analysis of various connection configuration of photovoltaic module under different shading conditions," International Journal of Applied Engineering Research, vol. 12, no. 16, pp. 5715-5720, 2017.
[17] J. Appelbaum, "Shading and masking affect the performance of photovoltaic systems - a review," AIMS Energy, vol. 7, no. 1, pp.77-87, 2019.

[18] T. A. Chandel, M. A. Mallick, and M. Y. Yasin, "Performance of partially shaded solar photovoltaic system," International Joumal of Recent Technologyand Engineering, vol. 7, pp. 1444-1449, 2019.

[19] P. Verma, and P. Basak, 'Programming based study of shading effect in a photovoltaic array," Intemational Joumal of Advanced Research in Electrical, Electronics and Instrumentation Engineering, vol. 5, no. 7, pp. 6206-6214, 2016.

[20] C. Deline, A. Dobos, S. Janzou, J. Meydbray, and M. Donovan, "A simplified model of uniform shading in large photovoltaic arrays," Solar Energy, vol.96, pp. 274-282, 2013.

[21] R. F. Gusa, W. Sunanda, I. Dinata, and T. P. Handayani, "Monitoring system for solar panel using smartphone based on microcontroller," in 2nd International Conference on Green Energy and Applications, IEEE, pp. 79-82, 2018.

[22] S. Priyadarshi, S. Bhaduri, and N. Shiradkar, "IoT based, inexpensive system for large scale, wireless, remote temperature monitoring of photovoltaic modules," in IEEE 7th World Conference on Photovoltaic Energy Conversion (WCPEC) (A Joint Conference of 45 th IEEE PVSC, 28th PVSEC \& 34th EU PVSEC), IEEE, pp. 0749-0752, 2018.

[23] X. Xiaoli, C. Tao, and Z. Yunbo, "Condition monitoring and diagnosis for grid-connected photovoltaic power system," in 2013 IEEE 11th Intemational Conference on Electronic Measurement \& Instruments, IEEE, vol. 2,pp.807-811.2013.

[24] H. Ibrahim and N. Anani, "Variations of PV module parameters with irradiance and temperature," Energy Procedia, vol. 134, pp. 276-285, 2017. 